\title{
RULE OF LAW CONCERNS IN THE CROATIAN PENAL ORDER PROCEDURE LINKED TO DEPRIVATION OF LIBERTY, JUDICIAL CONTROL, ADMISSIBILITY OF EVIDENCE AND PROCEDURAL RIGHTS****
}

Summary: $\quad$ The paper analyses the mechanism of a penal order as a consensual procedure aimed at relieving the criminal justice system in cases of minor criminal offences by avoiding a trial. The study aims to analyse the Croatian normative framework and case law in order to determine the distinctive traits of the penal order procedure in a comparative legal context, disclose the procedural reality and detect its shortcomings. The paper focuses on the substantive and procedural requirements for the issuing of a penal order, the judicial control of the indictment requesting a penal order, the defence rights in the proceedings before the issuing of a penal order and the position of the victim. These key elements were researched through normative, theoretical and comparative analysis of German, Austrian, Italian and French law and conclusions were tested in the case law of the Municipal Criminal Court in Zagreb and the Municipal Court in Split. The results of the research reveal that the expansion of the application of the penal order to graver offences punishable by five years of imprisonment and to more severe penalties such as deprivation of liberty, as well as deviations from some fundamental criminal procedural principles inherent in the penal order procedure, raise the question of providing adequate procedural guarantees for the defendant and the victim.

Keywords:

penal order, procedural safeguards, judicial review, consensual justice, criminal procedure, defence rights

\footnotetext{
Zlata Đurđević, PhD, Full Professor, Faculty of Law, University of Zagreb, Trg Republike Hrvatske 14, 10000 Zagreb, Republic of Croatia. E-mail address: zlata.durdevic@pravo.hr. ORCID: https://orcid.org/0000-0003-0155-442X.

** Marin Bonačić, PhD, Assistant Professor, Faculty of Law, University of Zagreb, Trg Republike Hrvatske 14, 10000 Zagreb, Republic of Croatia. E-mail address: marin.bonacic@pravo.hr. ORCID: http://orcid.org/0000-0001-9951-0921.

*** Marija Pleić, PhD, Assistant Professor, Faculty of Law, University of Split, Domovinskog rata 8, 21000 Split, Republic of Croatia. E-mail address: marija.pleic@pravst.hr. ORCID: https://orcid.org/0000-0001-8868-0079.

**** This paper has been fully supported by the Croatian Science Foundation under the project "Systematic approach to models of negotiated justice in Croatian criminal procedure" (IP-2019-04-1275).
} 


\section{INTRODUCTORY REMARKS}

The penal order (kazneni nalog) was the first consensual procedure introduced in the Croatian criminal justice system almost 25 years ago by the 1997 Criminal Procedure Act (CPA). ${ }^{1}$ It was a legally concise and narrowly constructed mechanism for petty offences, limited to sanctioning by mild penalties such as a fine, alternative sanctions and security measures. Meanwhile its normative framework expanded with regard to the gravity of offences and the severity of sanctions and consequently also its application in judicial practice. Contrary to the plea-bargaining mechanism which, as another kind of consensual legal mechanism, was introduced much later (in 2008) but captured the interest of legal scholars, the penal order has so far been an under-researched mechanism in Croatia from the normative, theoretical and practical perspective.

Currently, the penal order procedure in Croatia $^{2}$ empowers a state attorney to request a single judge of a municipal court to issue a judgment in the form of a penal order without holding a trial if there is a credible crime report on criminal offences punishable by up to five years of imprisonment. The state attorney's request should determine the exact type and gravity of punishment and/or measure. If the court agrees with the request, it will issue a penal order by a judgment appealable by the state attorney. ${ }^{3}$ If the court disagrees or if the defendant submits an objection, even unreasoned, against the penal order, the regular criminal proceeding will continue by conducting judicial control of the indictment and holding a trial. Therefore, the CPA envisages the penal order in the form of a one-sided and fixed offer by the state attorney on which the defendant cannot negotiate. ${ }^{4}$

The penal order procedure is based on the defendant's waiver of the right to a trial that implies some deviation from several criminal procedure principles, primarily the principle of an oral hearing, the principle of publicity, the adversarial and contradictory production of evidence, and the principle of the immediacy of the court assessment of evidence. ${ }^{5}$ Ultimately, however, the exclusion of these principles depends on the will of the defendant, since the defendant's objection to the penal order activates all procedural guarantees of regular criminal proceedings.

In Croatia, the penal order is extensively used in practice. In 2019, it was used in 5,949 indictments, which represents $38.5 \%$ of all indictments against adults in that year. Data for a five-year period (from 2015 to 2019) show that the proportion of indictments with a penal order in the total number of indictments filed against adults is relatively high and constant,

1 Zakon o kaznenom postupku, Official Gazette of the Republic of Croatia (Narodne novine), no. 110/1997.

2 Articles 540 to 545 of the Croatian Criminal Procedure Act. Zakon o kaznenom postupku, Official Gazette, no. 152/2008, 76/2009, 80/2011, 121/2011, 91/2012, 143/2012, 56/2013, 145/2013, 152/2014, 70/2017, 126/2019, $126 / 2019$.

3 The reasons for introducing the right to appeal were the cases in which the court issued a penal order that did not correspond to the request of the state attorney, Mazalin, S., Skraćeni postupak i ostali posebni postupci u Prijedlogu Zakona o kaznenom postupku, Hrvatski ljetopis za kazneno pravo i praksu, Vol. 15, No. 2, 2008, p. 769.

4 As Damaška states for the original form of the German penal order, Damaška, M., Napomene o sporazumima u kaznenom postupku, Hrvatski ljetopis za kazneno pravo i praksu, Vol. 11, No. 1, 2004, p. 4.

5 Krapac, D. et al., Kazneno procesno pravo. Prva knjiga: Institucije, Narodne novine, Zagreb, 2020, p. 119, Ivičević, E., Novosel, D., Vrste i mjere kazne primjenjivane u instrumentu kaznenog naloga i njihov odnos prema izrečenim kaznama, Hrvatski ljetopis za kazneno pravo i praksu, Vol. 11, No. 2, 2004, p. 676, Carić, M., Penal Order in the Light of Limitations and Excluding the Application of Certain Fundamental Principles of Criminal Procedure, Iustinianus Primus Law Review, Vol. 11, No. 2, 2020 , p. 4. 
ranging from 37\% in 2017 (5,507 indictments with a penal order out of a total of 14,864 indictments filed) to as much as $40.5 \%(6,046$ out of 14,936$)$ in $2018 .{ }^{6}$ In relation to legal persons, the percentage is slightly lower, and in 2019 the request for the issuance of a penal order was filed in 39 out of a total of 132 indictments, i.e. $29.5 \%$ and in the same five-year period the share of indictments with penal orders varied between $22.7 \%$ and $34.5 \% .^{7}$

The paper presents the results of the first part of comprehensive research on the penal order in the Croatian legal system, as part of the project "Systematic approach to models of negotiated justice in the Croatian criminal procedure" (NegJusCro), which examines the system of consensual proceedings in view of their specific objectives, the gravity of criminal offences to which they apply, the role of particular participants in the proceedings, especially the courts, the procedural guarantees, etc. ${ }^{8}$ Our research of the penal order procedure is divided into two parts: before and after the court decision on issuing a penal order. This paper deals with the first procedural stage and its focus on the following research variables: the substantive and procedural requirements for the issuing of a penal order, the judicial control of the indictment requesting a penal order, the defence rights in the proceedings before issuing a penal order, and the position of the victim. The aim of the paper is to analyse the normative framework and case law in order to determine the distinctive traits of the penal order procedure in Croatia in a comparative legal context, to disclose the procedural reality and detect its shortcomings. The normative analysis relies on previous research of the legislative framework ${ }^{9}$ enriched by a comparative perspective on the penal order in German, Austrian, Italian and French law, all of which to some extent influenced the development of Croatian criminal procedural law. In order to test the conclusions of the normative, theoretical and comparative analysis in practice, case-law research was conducted at two courts with the largest caseload in Croatia, the Municipal Criminal Court in Zagreb and the Municipal Court in Split, ${ }^{10}$ on 60 completed cases (30 in each court) from 2014 to 2020 in which the state attorney requested a penal order. Stratified accidental sampling was used, and includes two categories of cases: cases in which the judgment issuing a penal order became final and cases in which the court did not accept the request of the state attorney or where an objection or appeal was lodged. ${ }^{11}$ Taking into account that research sample is not representative, the data were presented statistically in order to describe them and test the results of previous empirical research and the research methods are the qualitative analysis of the content of the court files by different variables and

6 In 2015, a penal order was requested in 38.6\% (6054 of 15682) of all indictments and in 2016, 39.4\% (6,368 out of 16,136). Source: Statistical Reports of Croatian Bureau of Statistics: Adult Perpetrators of Criminal Offences, Reports, Accusations and Convictions for 2015, 2016, 2017, 2018 and 2019. https://www.dzs.hr. Accessed 27 January 2021.

7 2015: 24.2\% (45 of 186), 2016: 34.5\% (60 of 174), 2017: 22.7\% (33 of 145), 2018: 23.8\% (31 of 130). Source: Croatian Bureau of Statistics, First Release: Legal entities perpetrators of criminal offences, by type of decision for 2015, 2016, 2017, 2018 and 2019. https://www.dzs.hr. Accessed 27 January 2021.

8 Head of the project is Professor Elizabeta Ivičević Karas (Faculty of Law, University of Zagreb) and it is supported by the Croatian Science Foundation (2020 - 2024). For an overview, see Ivičević Karas, E., Consensual Justice in Croatian Criminal Procedural Law: The Need for a Systematic Approach, EU and Comparative Law Issues and Challenges Series (ECLIC), Vol. 4, 2019, pp. 405 - 432.

9 Bonačić, M., Kritički osvrt na hrvatsko zakonodavno uređenje instituta kaznenog naloga, Hrvatski ljetopis za kazneno pravo i praksu, Vol. 22, No. 1, 2015, pp. 185-216.

10 The authors would like to thank Judge Jasna Zoretić Rendulić, authorized to perform court administration at the Municipal Criminal Court in Zagreb, and Judge Tea Budimlić, President of the Criminal Department of the Municipal Court in Split, for enabling this research to be conducted at the demanding time of the COVID-19 pandemic. 
the case-law study. ${ }^{12}$ Given that there is no recent case-law research on this subject ${ }^{13}$, and that some aspects were never researched, ${ }^{14}$ the results of this paper will contribute to identifying the most problematic issues of the penal order procedure in practice.

\section{REQUIREMENTS FOR ISSUING A PENAL ORDER}

There are two main substantive and one procedural requirement for issuing a penal order by the judge. The first is related to the range of crimes for which a penal order can be rendered and the second is related to the sanctions that can be imposed by it. The procedural requirement is an evidential standard for issuing a penal order which in Croatia is formally termed the credible content of a crime report. However, beside these requirements prescribed by law, the Manual for the Work of State Attorneys reveals in practice that there is an additional negative requirement for the issuance of a penal order described as "public interest in conducting a trial" ${ }^{15}$ It lays down for state attorneys that requesting a penal order is generally justified "in all those cases where a milder sentence can be expected due to the perpetrator's conduct and the consequences for the protected value and legal system". ${ }^{16}$ However, if "from the perpetrator's manner of action, guilt and the consequences caused, it follows that the offence has a special gravity or that it has provoked significant public condemnation", the request for a penal order is not appropriate. ${ }^{17}$ Henceforth in this chapter we will deal with the requirements prescribed by law.

\subsection{THE RANGE OF CRIMES}

The normative development of the penal order since its introduction in the Croatian legal system by the 1997 CPA largely led to the expansion of its application in practice. The 2002 CPA amendments ${ }^{18}$ extended the range of criminal offences for which a penal order may be issued from criminal offences punishable by a fine or imprisonment of up to three years to imprisonment of up to five years. However, criminal offences punishable by imprisonment of up to five years that are under the jurisdiction of a judicial panel are excluded from the application of a penal order, keeping the prosecution of the gravest offences punishable by imprisonment of up to five years ${ }^{19}$ out of the penal order procedure.

12 The aim of this preliminary research was to identify the variables available in court decisions/files and to determine how the forthcoming main survey on practitioners' experiences and attitudes regarding the penal order procedure should be modelled.

13 See Novosel, D., Primjena kaznenog naloga u radu državnih odvjetništava, Hrvatski ljetopis za kaznene znanosti i praksu, Vol. 9 , No. 1, 2002, pp. 37 - 61. Ivičević, E., Novosel, D., op. cit. note 5, pp. 680 -698.

The evidential basis of the request for issuing a penal order, including the prior interrogation of the defendant, and the judicial review of the request for issuing a penal order.

Bonačić, M., op. cit. note 9, pp. 194-195.

16 Novosel, D. (ed.), Priručnik za rad državnih odvjetnika, Državno odvjetništvo Republike Hrvatske, 2011 , p. 497.

17 Ibid., p. 498.

18 Official Gazette, no. 58/2002.

19 Pursuant to Art. 19.b(3) CPA, the following crimes in the Criminal Code (Kazneni zakon, Official Gazette, no 125/11, 144/12, 56/15, 61/15, 101/17, 118/18, 126/19) are under the jurisdiction of the panel: manslaughter (Art. 112(2) and 
Comparative law also, as a rule, offers the possibility to issue a penal order for certain types of less serious offences. This is regulated by two types of restrictions, the first relating to the gravity of sanctions prescribed by the Criminal Code, and the second by excluding certain graver offences from the penal order procedure. In Germany, the penal order procedure (Strafbefehlen) is reserved for misdemeanours (Vergehen), that is, less severe criminal acts punishable by a fine or by less than the minimum sentence of one year of imprisonment. ${ }^{20}$ In Austria, in Mandatsverfahren, ${ }^{21}$ it is limited to offences punishable by up to three years of imprisonment that are under the jurisdiction of a single judge of a district or regional court. In Italian law, the simplified procedure (decreto penale) is available for ex officio offences and offences prosecutable upon complaint, punishable by a fine or imprisonment of up to six months that may be replaced by a fine. ${ }^{22}$ In France, an ordonnance pénal can be issued for petty offences (contraventions) ${ }^{23}$ punishable by fines and certain less grave offences (délits) enumerated in the law, punishable by imprisonment of up to five years with the exception of offences of wilful and unintentional attacks on the integrity of persons. ${ }^{24}$ Switzerland has the widest possible application with regard to the range of offences, applying a penal order to all offences. However, it should be stressed that the range of offences does not on its own tell us about the severity of the sentences that can be imposed by a penal order. As will be shown in the next chapter, all countries also restrict the type or severity of permissible sentence that can be imposed by a penal order.

As concerns the types of offences, the study conducted in 2002 by Novosel on a sample of 1,872 cases from 10 different municipal state attorney offices established that the penal order was most often requested for property offences in general, and, at the level of specific criminal offences, for theft (15.4\%), causing a road traffic accident (14\%), illegal hunting $(11.2 \%)$ and evasion of customs duty (9.4\%). ${ }^{25}$ The data from our research coincide with the results of Novosel's research in relation to the primacy of criminal offences against property. However, the main finding is that the penal order procedure is applied to a wide range of criminal offences. In a total of 60 analysed cases in Zagreb and Split, a penal order was requested for 22 different criminal offences, out of which theft (Art. 228 CC) occurred in 13 cases (21.6\%), threat (Art. 139 CC) in 10 cases (16.6\%), property damage (Art. 235 CC) and forging documents (Art 278 CC) in six cases each, five cases of causing a road traffic accident (Art. 227 CC), three cases of aggravated theft (Art. 229 CC), three cases of illicit trade (Art. 264 CC), two cases of fraud

(3) CC), negligent homicide (Art. 113 CC), participation in suicide (Art 114(2) CC), serious criminal offences against the health of people (Art. 192(2) CC), causing a road traffic accident (Art 227(6) CC), serious criminal offences against the environment (Art $214(4)$ CC) and serious criminal offences against general safety (Art. 222(4) CC). The provision lists the corresponding crimes of the previous 1997 Criminal Code. The jurisdiction of the panel can also be prescribed by a special act (Art. 19.b(4) CPA).

20 Section 407 et seq. of the German Code of Criminal Procedure (Strafprozeßordnung -StPO) https://www.gesetze-im-internet. de/stpo/StPO.pdf. Accessed 20 February 2021.

21 Section 491 of Austrian Code of Criminal Procedure, (Strafprozeßordnung -StPO) https://www.jusline.at/gesetz/stpo. Accessed 20 February 2021.

22 Art. 459 of the Italian Criminal Procedure Code, Codice di procedura penale - CPP, https://www.altalex.com/documents/codicialtalex/2014/10/30/codice-di-procedura-penale. Accessed 20 February 2021.

23 Article 524 et seq. of the French Code of Criminal Procedure (Code de procédure pénale, CPP) https://www.legifrance.gouv.fr/ codes/id/LEGITEXT000006071154/. Accessed 20 February 2021.

24 Art 495 et seq CPP, see 398-1 CPP.

25 Novosel, D., op. cit. note 13, pp. 47-48. 
(Art. 236 CC) and two cases of serious criminal offences against general safety (Art. 222 CC). These criminal offences were accompanied by thirteen criminal offences occurring only once. ${ }^{26}$ These data confirm the widespread application of the penal order.

\subsection{PERMISSIBLE SANCTIONS}

In regard to the penal order, the 1997 CPA allowed the issuing of a fine in the amount of ten to one hundred average daily incomes of the Republic of Croatia, judicial admonition, confiscation of the pecuniary gain obtained as a consequence of the commission of an offence and publication of the penal order in the media. It also allowed for the issuing of a prohibition to operate a motor vehicle and the seizure of objects (Art 446 CPA/97).

The 2002 CPA amendments considerably increased the severity of the imposed sentence in the penal order by introducing for the first time deprivation of liberty by a suspended sentence if imprisonment of up to three months was passed. The 2008 CPA extended a suspended sentence to imprisonment of up to one year and enabled the issuing of a penal order against legal persons (Art. 540.). ${ }^{27}$ Against natural persons, the following punishments or measures may be imposed by a penal order in Croatia: a) a fine in the amount of ten to one hundred average daily incomes or thirty to one hundred daily amounts; ${ }^{28}$ b) a conditional sentence of imprisonment of up to one year or a fine, or a judicial admonition; c) confiscation of the pecuniary gain acquired by a criminal offence and publication of the judgment with a penal order in the media; and d) prohibition to drive a motor vehicle for a period of up to two years or seizure of objects (Art. 540(2) CPA). Against legal persons, the following sanctions may be imposed: a) a fine of up to HRK 2,000,000.00; b) a conditional sentence with a fine; c) confiscation of the pecuniary gain acquired by a criminal offence and publication of the judgment with a criminal order in the media (Art. 540(3) CPA). In addition to these measures, the court must impose the confiscation of pecuniary gain acquired by a criminal offence if it does not uphold the pecuniary claim of the injured person (Art 540(4) CPA).

It can be seen that unconditional imprisonment may not be requested by a penal order, as a punishment as severe as the deprivation of liberty requires much stronger safeguards. However, this is just a smoke screen as a penal order procedure may result in imprisonment of even up to one year in cases where a convicted person does not fulfil the conditions ordered in the suspended sentence or where he or she commits a new crime.

In other analysed comparative systems, the law also enumerates the sanctions and measures that can be imposed. What all countries have in common is that a fine (not exceeding a

26 Among others, these are criminal offences against the environment, against property, against the economy, the judiciary and public order.

27 Official Gazette, no. 152/2008.

28 It depends on which Criminal Code is applied. "Average daily incomes" are used when the 1997 Criminal Code is applied, and "daily amounts" when the 2011 Criminal Code is applied, as this Code changed the concept of a fine and introduced "daily amounts". 
certain amount) can always be imposed rather than unconditional imprisonment which is generally not permitted. However, Swiss law stands out as an exception where a public prosecutor can impose through a penal order a custodial sentence of up to six months. ${ }^{29}$ Following the severity of the punishment, in Germany and Austria a penal order may impose a suspended prison sentence of up to one year, while the most lenient countries are France and Italy where prison sentences in any form are excluded. France provides for a fine not exceeding EUR 5,000 and alternatives to a prison sentence, and in Italy the public prosecutor may request a penalty reduced by a maximum of half of the minimum amount prescribed. The application of accessory penalties, except for the confiscation of the seized objects, is not allowed.

As for the application of other measures, several types of restrictions are envisaged. For example, in Italy, a judge through a penal order cannot impose on an accused the obligation to pay the costs of the proceedings. Similarly, the costs of the proceedings are also not listed in the Croatian CPA as something that the state attorney may request from the court.

As regards the imposition of permissible sanctions in practice, Ivičević and Novosel established in research conducted in 2004 that there were no major differences in the penalties imposed on the basis of a request for a penal order and those imposed for the same criminal offences in judgments in which the state attorney did not request a penal order, and that in both groups the dominant sentence was a suspended sentence of imprisonment, usually for more than one month. ${ }^{30}$ The results of our research also confirm that the suspended sentence of imprisonment is the most common sentence in cases involving a penal order, as this was imposed in all cases in Zagreb and in 90\% (27 out of 30) of the cases in Split.

Therefore, it can be concluded that the speedy procedure without a trial in the form of a penal order introduced in 1997 has been transformed in law and in practice from a procedure excluding any conditional or unconditional deprivation of liberty to a procedure regularly imposing imprisonment in the form of a suspended sentence.

\subsection{CREDIBLE CRIME REPORT (EVIDENTIAL BASIS FOR ISSUING A PENAL ORDER)}

A credible crime report is the requirement related to the evidential basis for issuing a penal order. The state attorney may request a penal order if he or she has learnt of the criminal offence on the basis of the "credible content of a crime report" (Article 540(1) CPA). This is an evidentiary standard, like other degrees of probability that a defendant has committed a crime, none of which are defined by the CPA. However, its content was established by the Constitutional Court of the Republic of Croatia in 2012 in a decision on the constitutionality of Article 540(1) CPA. ${ }^{31}$ This provision was challenged because it did not define the notion of the

29 For details Enescu, R., Penal Orders and the Role of Prosecutors in Switzerland, Journal of Legal Studies Volume 26 Issue 40/2020, p. 129; Gillièron, G., Public Prosecutors in the United States and Europe: A Comparative Analysis with Special Focus on Switzerland, France, and Germany, Springer, 2014, pp. 225 - 227. 
credible content of a crime report, and a crime report is not evidence in criminal proceedings (para. 448):

"The Constitutional Court notes that by the notion of 'credible content of the crime report' the CPA has in mind the crime report which is sufficient for the conclusion that the defendant committed a criminal offence within the jurisdiction of a single judge. This notion encompasses not only credibility in terms of truthfulness but also a high degree of probability. In this way, the criminal report becomes a source of knowledge about the criminal offence and the perpetrator, and after examination, in the case of the issuance of a penal order, it acquires the meaning of evidence. It is an evidentiary standard assessed by the court. In this sense, it can be equated with other evidentiary standards in which the CPA includes both 'grounds for suspicion' and 'reasonable suspicion', which are also not legally defined. Based on these standards, decisions are made in criminal proceedings." 32

The problem is that the high degree of probability or certainty that is required in Croatia to deliver a judgment on conviction, which in fact is what a judgment issuing a penal order is, in most cases cannot be reached on the basis of an initial or supplemented crime report. That is not recognized in the $\mathrm{CPA},{ }^{33}$ which presumes that a penal order is based on a credible crime report. Chapter 26 of the CPA prescribing the procedure for issuing a penal order does not mention any other inquiry or evidential action. However, the fact that in practice a prosecutorial request for a penal order is never based solely on a credible crime report ${ }^{34}$ is clearly stated in the Manual for the Work of State Attorneys. It requires that before filing a request for a penal order, the state attorney must, in terms of Art. 341(4) CPA, ${ }^{35}$ interrogate the defendant, and obtain information on the suspect, especially on their assets, information on previous sentencing or ongoing proceedings and only then can a decision be taken as to whether an indictment requesting a penal order is to be made. ${ }^{36}$ Due to this practice, and considering comparative solutions, it has already been proposed in Croatian literature to abandon the credible content of a crime report as a requirement for issuing a penal order. ${ }^{37}$

The analysed comparative legislation, in the circumstances of prosecution by a penal order, also clearly requires the establishment of responsibility for a crime the defendant has been charged with by the prosecutor in an official inquiry, preliminary investigation or investigation. Thus, French law requires it to result from a judicial police inquiry that the facts the defendant is accused with have been established and that enough information about the defendant's income

32 Ibid., par. 450.

33 Bonačić states that the request that the state attorney has "learnt of" the criminal offence on the basis of the credible content of a crime report would lead to the unacceptable result of the impossibility of requesting the issuance of a penal order in all cases where the state attorney did not learn about the crime on the basis of a crime report or where it initially did not contain sufficient evidence to convict the defendant, i.e. it was not based on "credible content" at the time of submission. Bonačić, M., op. cit. note 9, p. 192-193.

34 Even though this report may also include urgent evidentiary actions taken by the police due to the danger of delay before filing a criminal report.

35 Article 341(4) CPA: Before the indictment is filed, the defendant must be examined, unless an indictment in absentia is proposed in the indictment.

36 Novosel, D., op. cit. note 16, p. 497.

37 Bonačić, M., op. cit. note 9, pp. 194 and 214. 
and expenses to allow the penalty to be determined has been obtained. ${ }^{38}$ The Austrian StPO requires that the results of the preliminary investigation in connection with the responsibility of the accused are sufficient to assess all the circumstances decisive for the question of guilt and criminal offence. ${ }^{39}$ Both Austrian and French law provide for an additional requirement relating to a victim whose rights and interests must not be infringed by the penal order procedure. German criminal procedure law prescribes that the public prosecutor may request the issuance of a penal order if it does not consider a main hearing to be necessary given the outcome of the investigations (section 407 para. 1 StPO). Italian law requires that the request for a penal order together with the case file be submitted within six months of the date of registration of the suspect's name in the register of crime reports (notitiae criminis). The case file contains the crime report, the documentation relating to the investigations carried out, as well as records of judicial police activities. ${ }^{40}$ However, there are cases where prosecutors request penal orders based only on a crime report, without conducting any official investigation into the reliability of the accusation. ${ }^{41}$ In Switzerland, if during police enquiries or the investigation the accused accepts responsibility or responsibility has otherwise been satisfactorily established, the prosecutor will issue a summary penalty (Article 352 (1) CPA). In preliminary proceedings, one of the purposes of the enquiries is to gather evidence in order to establish whether a summary penalty order should be issued to the accused (Art. 299 (2a) CPA). Furthermore, the prosecutor does not have much discretion in deciding whether to issue a penal order but is obligated to follow this procedure as soon as the requirements are met. ${ }^{42}$

\subsubsection{Case-law research: determining the credibility of a crime report}

Case-law research has confirmed that state attorneys in a number of cases have taken other evidentiary actions or have ordered them to be taken prior to the indictment. The most frequent is the examination of witnesses (including the examination of the victim), but also expert examinations and temporary seizure of objects or documents. Procedurally, this means that the state attorney has decided to start a simplified investigation (istraživanje, Art. 213(1) $\mathrm{CPA})^{43}$ as the first stage of criminal proceedings ${ }^{44}$ for offences punishable by up to five years of imprisonment and to conclude with a penal order. The substantive requirement for the start of a simplified investigation is the establishment of reasonable suspicion that a suspect has committed a criminal offence. The formal requirement is that the state attorney delivered the notice on taking evidentiary actions to the defendant within three days from taking the

\footnotetext{
38 Art 495-1 CPP.

39 Section 491, paragraph 3 StPO.

40 Gaito, A. (ed), Codice di procedura penale, Commentato, Utet Giuridica, 2012, p. 3028.

41 Thaman, S.C., The Penal Order: Prosecutorial Sentencing as a Model for Criminal Justice Reform? in: Luna, E., Wade, M. (eds): The Prosecutor in Transnational Perspective, Oxford University Press, 2012, p. 168.

42 Gillièron, G., op. cit. note 26, p. 225.

43 According to Art 213(1) CPA, a simplified investigation can be conducted when there is a reasonable suspicion that the defendant committed a criminal offence punishable by a fine or by imprisonment for up to five years with the purpose of conducting evidentiary actions which are "purposeful" for deciding on indictment.

44 However, in Croatia criminal proceedings for offences punished by up to five years of imprisonment start formally with the confirmation of indictment.
} 
first evidentiary action. In the stage of a simplified investigation, the criminal proceedings are no longer secret, the defendant's defence rights are guaranteed, and judicial control of the legality of the prosecution is activated. ${ }^{45}$ So, in accordance with the CPA, the state attorney in each case where he or she takes evidentiary action during simplified investigation must previously have established reasonable suspicion which is a higher degree of probability than the grounds for suspicion required for a police inquiry and must have sent the notice about it to the suspect. The data from the case-law research show that the formal requirement has been respected. However, to verify the existence of reasonable suspicion it would be necessary to carry out a thorough case study for each file which lies outside the scope of this research.

In any case, it can be concluded that the original concept of the penal order introduced by the CPA/1997 that remained normatively unchanged in CPA/2008 was in practice changed and abandoned. A crime report in the Croatian criminal procedure is filed with a state attorney who can then start an inquiry, investigation or a simplified investigation. The concept of a credible crime report originally meant that there is no need to verify the truthfulness of the allegations in the crime report regarding the existence of the criminal offence, its consequences and guilt even through (additional) inquiries, ${ }^{46}$ let alone by conducting evidentiary actions or the whole stage of criminal proceedings such as a simplified investigation. The case-law research, however, suggests that there is in fact no substantive difference in the activities of the state attorney during the preliminary proceedings depending on whether or not she or he requires the issuance of a penal order, since such a request is rarely based solely on the content of the crime report. On the other hand, a simplified investigation does not give the state attorney the power to terminate it with the request for a penal order. Therefore, it is clear that prosecutorial practice that was accepted by the courts introduced a penal order mechanism at the stage of simplified investigation which is also set up for the prosecution of criminal offences punishable by up to five years of imprisonment (Article 213 CPA).

\subsubsection{Interrogation of the defendant}

There was an open question whether the obligation of the state attorney to interrogate the defendant before filing an indictment pursuant to Art. 341(4) CPA applies to the issuing of a penal order. Art 540 CPA does not provide for the interrogation of the defendant by the state attorney before requesting the issuance of a penal order in the indictment. However, the Supreme Court of the Republic of Croatia took a stand on this matter in a decision on a request for protection of legality. It established that rendering a judgment on a penal order violated the law, inter alia, due to the fact "that the accused was [not] interrogated at all which is a formal condition for filing any indictment and thus [the judgment was rendered] without a credible crime report attached to the indictment" ${ }^{47}$

45 After the defendant has received the notice, he or she has the right to inspect the case file (Article 184(4)(3) CPA), to file the motion for the taking of evidentiary action to the state attorney and the judge and to file a complaint in case of violation of defence rights or if there is no reasonable suspicion that he or she committed a criminal offence. Article 239a (1 and 2) CPA.

46 Krapac, D., Zakon o kaznenom postupku i drugi izvori hrvatskog kaznenog postupovnog prava, Narodne novine, Zagreb, 2008 , p. 678. 
Croatian academics and legal writers disagreed and claimed that the CPA does not prescribe an obligation of prior interrogation of the defendant in the penal order procedure. The arguments are that the rule under Art. 540 is lex specialis in relation to the general provision on the obligation to interrogate the defendant ${ }^{48}$ and that there are no procedural sanctions provided for a breach of that obligation. ${ }^{49}$

Our case-law research has shown that the defendant was in all cases interrogated before the request for issuing a penal order. In approximately $65 \%$ of cases, the defendant was interrogated by the police, and in $35 \%$ of cases by the state attorney (sometimes the defendant was questioned only by the state attorney, and sometimes the state attorney did so after a police interrogation).

The disputed issue in Croatian legislation related to the obligation to interrogate the defendant before issuing a penal order was resolved in the Austrian StPO. It is explicitly established as a procedural requirement for issuing a penal order together with the explicit waiver of the main trial. Other observed comparative legislations do not have such a provision. In Italy, the public prosecutor is not required to question the suspect before submitting a request for a penal order. The prevailing view in Italian jurisprudence is that the provision on the notice to the suspect on the conclusion of preliminary investigations after which the suspect may request to be questioned (Art 415 bis CPP) is excluded from applying in penal order proceedings. It is considered to be in conflict with the principle of the maximum speed of alternative procedures and in any case because the defence can express in the trial phase any opposition to a penal order. ${ }^{50}$ In Germany, the public prosecutor does not have the duty to examine the accused prior to the submission of the application for a summary penal order. ${ }^{51}$ Although in Switzerland a public prosecutor is also not obliged to hear the defendant before issuing a penal order, there are proposals for changes of legislation whereby the public prosecutor will have the obligation to hear a defendant if the sanction includes a prison term..$^{52}$ According to Danish law, the accused must be heard by the prosecutor when a penal order consists of certain (enumerated) sanctions and measures. It is stated, however, that it would be reasonable to set such an obligation in cases where the evidential basis is rather small..$^{53}$

48 Pavičić, A., Bonačić, M., Skraćeni postupak prema novom Zakonu o kaznenom postupku, Hrvatski ljetopis za kazneno pravo i praksu, Vol. 18, No. 2, 2011, p. 513.

49 "It is not provided as a reason for rejecting a request for a penal order, nor as a violation which the indictment panel examines during its (subsequent) review." Bonačić, M., op. cit. note 9, p. 196. See also Klier, D., Kondor-Langer, M., Gluščić, S., Policijska i državnoodvjetnička praksa u ispitivanju osumnjičenika, Hrvatski ljetopis za kaznene znanosti i praksu, Vol. 25, No. 2, 2018, pp. 454-455 and Carić, M., Istraživanje - zakonodavni okvir i praktična primjena, Hrvatski ljetopis za kaznene znanosti i praksu, Vol. 25, No. 2, 2018, p. 524.

50 Cassazione penale, Sez. III, sentenza n. 16894 of 23 April 2015. See also Gaito, A., op. cit. note 40, p. 3029.

51 According to section 163a StPO, in simple matters, it is sufficient to give the accused the opportunity to respond in writing before investigation is concluded. See Gillièron, G., op. cit. note 29, p. 279.

52 Enescu, R., op. cit. note 29, p. 134.

53 Vriend, K., Avoiding a Full Criminal Trial, Fair Trial Rights, Diversions and Shortcuts in Dutch and International Criminal Proceedings, Springer, 2016, p. 56. 


\section{JUDICIAL REVIEW BEFORE ISSUING A PENAL ORDER}

The issuing of a penal order in Croatia, as in most other countries, falls under the competence of judicial authority. ${ }^{54}$ However, there are some comparative legal systems, such as those of Switzerland and Denmark, that allow a prosecutor to issue a penal order and hence extend the judicial prerogative of imposing sentences to the prosecutor. ${ }^{55}$ In these two countries, a penal order is issued without judicial involvement, and judicial review follows only after an objection has been lodged. ${ }^{56}$

In Croatian criminal procedural law, a single judge before deciding on a request for a penal order also performs limited control of the indictment containing it. The substantive ground for dismissing the request is the opinion of the single judge that the information contained in the indictment does not provide sufficient grounds for the issuance of a penal order or that according to this information the imposition of some other punishment or measure rather than the one requested by the state attorney may be expected (Art 543(2) CPA).

In respect of the request itself, the single judge will dismiss it if it is related to a criminal offence, punishment or measure that is not permitted under law (Art. 543 para 1 (2) and (3) CPA) or if there are procedural obstacles for prosecution. ${ }^{57}$ Compared to the regular judicial review of the indictment, the single judge does not examine whether the indictment was filed within the time limits prescribed by law, whether the indictment contains all the components, and whether the case file contains evidence to be excluded. ${ }^{58}$ From the fair trial perspective, the most important difference is disregard of illegal evidence as this can lead to the possibility that a penal order is founded on the illegal evidence. This is particularly concerning given the results of the previous chapter, where the state attorney does not decide to request a penal order on the basis of a credible crime report but conducts a simplified investigation including different evidentiary acts whose legality is not examined. This limited judicial review came under the critique of Bonačić who proposed that it should be broadened to include all the requirements which are examined by the president of the panel during the preliminary examination of the indictment (Art. $344 \mathrm{CPA}) .^{59}$

54 Cf. Thaman, S.C., op. cit. note 41, p. 169.

55 Vriend, K., op. cit. note 53, p. 54.

56 For Denmark see ibid., p. 55. According to Swiss law, after the objection has been lodged the prosecutor gathers additional evidence to assess the objection and then decides whether he or she will uphold the penal order, abandon the proceedings, issue a new penal order, or bring charges at the court of first instance. Enescu, op. cit. note 29, p. 131.

57 The single judge will also dismiss the request if there are grounds to discontinue proceedings: the prosecutor has dropped the charges, there was no request from the authorized prosecutor, the required prosecution motion was not filed or the required prosecution authorization was not given or it was withdrawn, the accused has already been convicted or acquitted by a final judgment of the same offence, the proceedings against him or her for the same offence were discontinued by a final decision (except the one referred to in Art 500 CPA), or the accused has been exempted from criminal prosecution by amnesty or pardon or if the period of limitation for criminal prosecution has run or if other circumstances barring criminal prosecution exist (Art. $543(1)(1)$ CPA).

58 For details, see Bonačić, M., op. cit. note 9, pp. 198-201. The CPA does not require that the judge examine whether the defendant was interrogated before the indictment was filed, but considering that after the Supreme Court decision it has become obligatory, it can be presumed that the judge controls this requirement. 
In the case-law research, it was shown that out of 60 cases the request was not accepted in six cases, all of them before the Municipal Criminal Court in Zagreb. Unfortunately, the single judge does not have to explain the decision rendered, so it is not possible to see what the grounds for the decision were. However, in two cases there was a handwritten remark stating that the judge did not agree with the proposed sanction, and in a third case that the state attorney did not put forward a motion to the court to decide on the pecuniary claim.

If the single judge did not accept the request or if the defendant lodged a complaint against the judgment issuing a penal order, the indictment will be served on the defendant who has the right to respond to it and then it will be reviewed by the indictment panel (Art 542(5) CPA). However, the panel does not perform a full review of the indictment, but only with regard to whether it was preferred by an authorised prosecutor, properly drawn up and preferred within the prescribed time limit. ${ }^{60}$ However, it does not review the admissibility of evidence on which the existence of the reasonable suspicion is based as it would after a regular simplified investigation.

The results of the case-law research of this phase indicate that the indictment was confirmed in 11 out of 12 cases before the Municipal Court in Split and in all 14 cases before the Municipal Criminal Court in Zagreb. In Split, two indictments were returned for clarification and, in one case, the panel dismissed the indictment because there were grounds precluding prosecution because the legal person ceased to exist. In Zagreb, in one case the indictment was returned for clarification.

Comparative research reveals that there are differences between comparative legal systems in terms of the scope of judicial control. In Italy, the preliminary investigation judge after receiving an indictment with a request for a penal order must first verify whether the case file reveals elements such as to render a sentence of acquittal pursuant to Art $129 \mathrm{CPP} .^{61}$ Verification of the existence of the causes of acquittal is preliminary and, if it is unsuccessful, a judge assesses the admissibility and validity of the request. Jurisprudence considers that dismissal must also be pronounced when an "absolute lack" of proof against the charge is found. When proof of guilt is missing but it is expected that it can be integrated in the trial, the judge returns the case file to the public prosecutor. ${ }^{62}$ The decision on returning the case file must be reasoned. ${ }^{63}$ In France, a presiding judge, upon receiving a case file and request, decides whether there are reasons for acquittal. If the judge considers that a hearing is necessary or that a prison sentence should be imposed, she or he returns the case file to the public prosecutor. ${ }^{64}$ Even though French law offers the judge the possibility of modifying the amount of the fine proposed by the prosecutor or of acquitting the defendant, in practice the judge systematically

60 Art. 229(2) CPA and Art. 365(2) CPA.

61 Art 459 (3) CPP. According to Art. 129 (1), at any stage and instance of the proceedings after the initiation of criminal prosecution, the court that acknowledges that either the criminal act did not occur or the accused did not commit it or the act does not constitute an offence or it is not deemed an offence by law or the offence is extinguished or a requirement for prosecution is not met, shall declare so of its own motion by issuing a judgment.

62 Gaito, A., op. cit. note 40, p. 3032.

63 Ibid., p. 3035.

64 Art 495-1 CPP. 
accepts the prosecutor's proposal. ${ }^{65}$ In Austria the court must establish first that there is no reason for the discontinuance of proceedings, and, if it deems it necessary to clarify the prerequisites for issuing a penal order, it may question the accused and the victim. ${ }^{66}$ In Germany, if the judge considers that there are insufficient grounds to suspect that the accused person who has been indicted has committed an offence, the judge will refuse to make a summary penal order. Furthermore, the judge must set a date for the main hearing if she or he has reservations about deciding on the case without a main hearing, if she or he wishes to deviate from the legal assessment in the request to issue a summary penalty order, or if she or he wishes to impose some other legal consequence. ${ }^{67}$

Therefore, it can be seen that in the comparative context the judicial review of a charge before a trial focuses on the evidence, reviewing whether sufficient probability has been established to move into the trial stage, or, if there is a lack of proof or for other reasons, for acquittal. The Croatian law disregards the admissibility of evidence in the judicial review of the indictment before or after issuing a penal order even though a penal order in practice is requested and issued not on the basis of a crime report but on the basis of evidence collected before or during the simplified investigation. There is no justification for omitting in the penal order procedure the exclusionary rule ${ }^{68}$ guaranteed by Art 29(4) of the Constitution of the Republic of Croatia which prohibits the use of illegally obtained evidence in court proceedings. ${ }^{69}$ Therefore, compared to the judicial review of the indictment in proceedings where the state attorney has not requested a penal order, there is a substantial lowering of the fair trial guarantees and the extent of the judicial review of the legality of the investigation and evidentiary acts.

\section{THE RIGHTS OF THE DEFENDANT BEFORE ISSUING A PENAL ORDER}

The rights of the defendant are protected by the already discussed judicial control that prevents the passing of a judgment issuing a penal order in cases where there are procedural impediments or where there is no evidence that the person has committed a criminal offence. This chapter will examine the defendant's rights before the issuing of a penal order stricto sen$s u$. Inherent to the penal order procedure is the restriction of different defence rights unless the defendant objects to the judgment on the penal order. If the defendant does not object, it is deemed that he or she has waived the majority of the fair trial rights. Since there is the danger of an unjustified conviction, it is particularly important to check what defence rights a defendant can exercise before the issuing of a penal order.

\footnotetext{
65 Gillièron, G., op. cit. note 29, p. 304.

66 Section 491, subsect. 2 and 3 StPO.

67 Section 408 , subsect. 2 and 3 StPO.

68 Bonačić, M., op. cit. note 9, p. 205. 
In this regard, the position of the defendant differs depending on whether the defendant is under a simplified investigation before the issuing of a penal order. In its original form, the penal order procedure did not foresee the participation of the defendant and their defence rights. The transposition of the EU Defence Rights Directives enforced the already mentioned decision of the Supreme Court that the defendant has to be interrogated before the judgment issuing a penal order. ${ }^{70}$ Interrogation of the defendant can be considered crucial for the exercise of the defendant's rights of defence and it should be explicitly stipulated in the CPA. In some instances, this interrogation could be the only opportunity for the defendant to receive a letter of their rights before the issuing of a penal order. In addition, at that moment the authority conducting the interrogation has to instruct the defendant of their rights in an understandable manner, and to check whether the defendant understands the official language of the court. ${ }^{71}$ The interrogation of the defendant precludes a situation in which a penal order would be issued against the defendant without first knowing that he or she is charged with committing a criminal offence. It also contributes to the realization of the principle of adversarial proceedings and the better acquaintance of the state attorney with the factual situation, ${ }^{72}$ which reduces the possibility of submitting unjustified requests for the issuance of a penal order.

Defence rights were more widely applied in the penal order procedure by state attorneys conducting simplified investigation. In such a case, the state attorney has to deliver the notice on the taking of evidentiary actions to the defendant within three days of taking the first action (Art. 213(2) CPA). After receiving the notice, the defendant may propose evidentiary actions to the state attorney, and to the judge of investigation an evidentiary hearing ${ }^{73}$ (Art. 213(4) CPA)..$^{74}$ Together with the notice, the defendant has to receive the letter of rights (Art 239(2) CPA), which contains the following information: a) what the defendant is accused of and what the grounds of the suspicion are; $b$ ) that the defendant is not obliged to present a defence or answer questions; $c$ ) that the defendant is entitled to inspect the case file after the delivery of the notice; ${ }^{75} \mathrm{~d}$ ) that the defendant has the right to use their native language or the language which they speak and understand, as well as the right to an interpreter; e) that the defendant has the right to retain a defence counsel of their own choosing or that one will be appointed, or an ex officio defence counsel or a defence counsel paid by the budget if due to their financial condition they are unable to pay the costs of defence.

$70 \quad$ Supra note 47.

71 If in doubt, the authority conducting the interrogation has to ensure the participation of an interpreter (Art 273(6) CPA).

72 Petković, N., Pajčić, M., Kazneni progon, istraga i optuživanje - nova iskustva, Hrvatski ljetopis za kaznene znanosti i praksu, vol. 18, no. 2, 2011, p. 438.

73 According to Art. 236 CPA, an evidentiary hearing is conducted when: 1) it is necessary to interrogate a child or a witness under the terms of international agreement; 2) it is necessary to interrogate witnesses relieved of the duty to testify if there is a fear that they will not testify at the hearing; 3) it will not be possible to interrogate the witness at the trial; 4) the witness is exposed to an influence which brings into question the truthfulness of his testimony; 5) it will not be possible to present another piece of evidence at a later time. almost one thousand simplified investigations, they requested the conducting of evidentiary actions from the state attorney in only $4 \%$ of the cases and did not request the conducting of evidentiary hearing even once. Carić, M., op. cit. note 49 , p. 528 . 
Comparative research shows that there are systems which provide strong participatory rights and procedural guarantees to the defendant before the issuing of a penal order. Austrian law requires not only that the defendant be questioned but also, after having been informed of the consequences, that she or he has expressly waived a main hearing. It has also been stated that penal order proceedings in Italian law protects to a certain extent the participatory rights of the accused more than in ordinary criminal proceedings. ${ }^{76}$ Thus, if the service of a penal order cannot be carried out because the accused cannot be traced, the preliminary investigation judge must revoke the penal order and return the case file to the public prosecutor. ${ }^{77}$ The penal order also has to be served on the defendant's lawyer or, where no lawyer was appointed by the accused, to a court-appointed lawyer. The Constitutional Court acknowledged the lawfulness of opposition filed by a lawyer, irrespective of whether appointed by the accused or by the court, when the accused is untraceable. However, as it is stated, this can aggravate the position of the accused in the case where the lawyer's initiative may differ from the accused's intentions and can entail the loss of some benefits if the penal order is revoked. ${ }^{78}$

Unlike Croatian legislation which does not require legal assistance during a penal order procedure at all (the penal order procedure does not fall under the scope of mandatory legal assistance and the right to free legal aid is provided after the commencement of the simplified investigation under the conditions of Art. 72. CPA), German and Austrian law allow for the imposition of a suspended prison sentence by a penal order only if the defendant is represented by a defence attorney.

\section{THE POSITION OF THE VICTIM}

The position of the victim in penal order proceedings will be examined here with regard to the rights that may affect the decision on the penal order. Under the CPA, the victim of a criminal offence can have two roles: the role of "victim" and the role of "injured person", each with a specific set of rights. The victim is "a person who suffered physical and mental consequences, pecuniary damage or significant violation of fundamental rights and freedoms which are a direct consequence of the criminal offence" (Art. 202(2)11 CPA). On the other hand, the injured person is "the victim of a criminal offence and the legal person to whose detriment the criminal offence was committed, which participates as the injured parties in the proceeding" (Art. 202(2)12 CPA). Since criminal procedure in the case of a penal order commences upon the rendering of a judgment issuing it (Art 17(1) CPA), the victim cannot become an injured person before the issuance of the penal order. The consequence would be that the victim in a penal order procedure could not use the rights provided for the injured person. However, this is clearly a mistake by the legislator after introducing the notion of victim. The only change in

76 Ruggeri, S., Audi Alteram Partem in Criminal Proceedings, Towards a Participatory Understanding of Criminal Justice in Europe and Latin America, Springer International Publishing AG, 2017, p. 62.

77 Art 460(4) CPP

78 Ruggeri, S., op. cit. note 76, p. $61-62$. 
the provisions on the penal order due to the transposition of the Victims' Rights Directive ${ }^{79}$ was that the 2017 amendments ${ }^{80}$ prescribed that a penal order is served on the "victim" instead of the "injured person".

\subsection{PARTICIPATORY RIGHTS OF THE VICTIM IN A PENAL ORDER PROCEDURE}

One of the rights that can affect the decision on issuing a penal order is the right of the victim to be heard without an unjustified delay after the crime report with regard to a criminal offence has been made (Art 43(1) CPA). Even though it is not prescribed that the victim has to be interrogated before the request for issuing a penal order, this general provision on the victim's rights implies it should be done. The victim also has the right to be informed by the state attorney of the acts performed as a result of the victim's crime report upon the expiry of two months from the submission of the crime report and the right to complain to a senior state attorney. Among other rights is the right of the victim and the victim's proxy to inspect the case file (Art 184(2) CPA). If prior inspection of the case file would influence the testimony of the victim or the injured party, they will have the right to inspect the case file only after they have been examined. This applies also to the state attorney's case file. ${ }^{81}$ However, the victim does not have the crucial tools to influence the outcome of the proceedings. Such a tool is the right to draw attention to facts and produce evidence, which is provided only for the injured person (Art. 54(1)4 CPA).

Comparative analysis indicates that the role of the victim in penal order proceedings is not significant, and it is usually narrowed to the possibility to submit a pecuniary claim, although in some systems even this is not available (Italy). French and Austrian law have shown a more victim-oriented approach where, as stated before, they explicitly require that recourse to a penal order procedure is not likely to infringe the rights of the victim (Art $495 \mathrm{CCP}$ ), i.e. that the rights and legitimate interests of the victim are not impaired (Section 491(3) StPO). The victim in Austrian mandate proceedings may be summoned if the court deems it necessary to decide on a penal order and the victim has the right to raise an objection to the court issuing a penal order.

Art. 540(4) CPA requires the state attorney to put forward a motion to the court to decide on the pecuniary claim of the "injured person" if it is claimed. However, in a penal order procedure only a victim takes part and, according to the wording of the Croatian CPA, she or he cannot file for a pecuniary claim ${ }^{82}$ since it is listed only as a right of an injured person, and not a victim (Art. 153(1) CPA).

79 Directive 2012/29/EU of the European Parliament and of the Council of 25 October 2012 establishing minimum standards on the rights, support and protection of victims of crime, and replacing Council Framework Decision 2001/220/JHA, OL 315/57.

80 Official Gazette, no. 70/2017.

81 Art 110(3) of the Rules of Procedure of State Attorney's Office (Poslovnik državnog odvjetništva, Official Gazette, no. 128/2019). 
As regards this right in comparative law, it has been highlighted that Italian law on penal order proceedings shows certain deficiencies regarding the victim's rights. Thus, the CCP of 1988 did not allow for the aggrieved party to join a civil law action to criminal proceedings when the prosecutor requested a penal order, ${ }^{83}$ and the Constitutional Court confirmed such a legal solution as constitutional. ${ }^{84}$ French law provides for different legal positions and a different procedure for a victim depending on whether and when the victim filed a civil party petition, before or after the issuance of a penal order, ${ }^{85}$ and whether the penal order is issued for a misdemeanour (délit) ${ }^{86}$ or for a petty offence (contravention) but, in any case, the court has to decide on civil interests upon the victim's request.

According to the German StPO, the victim as a potential joint plaintiff to the prosecution does not have legal remedy to challenge the decision issuing a penal order without a main hearing. In proceedings involving penal orders, the declaration to join as a private accessory prosecutor will take effect when a date for the main hearing has been set or a request for the issuance of a penal order has been refused ${ }^{87}$ A recent European Court of Human Rights judgment in Gray v. Germany of 2014 revealed some problematic issues regarding the penal order procedure from the perspective of the participatory rights of the aggrieved party. ${ }^{88}$ Although the applicants complained under Article 2 of the European Convention on Human Rights that shortcomings in the British health system led to their father's death as a consequence of medical malpractice by a German doctor, the crucial points were related to the penal order procedure. ${ }^{89}$ First, the summary criminal proceedings instituted against the doctor in Germany had not involved a proper investigation or scrutiny of the facts of the case, and, second, that the German authorities had failed to inform the applicants of the proceedings and had thus deprived them of any possibility to become involved and participate in the proceedings. ${ }^{90}$ However, the Court concluded that the decision to issue a penal order without previously notifying the applicants did not affect their legitimate interests as aggrieved persons or potential joint plaintiffs to prosecution. Since the circumstances of the case had been sufficiently established in the course of the investigative proceedings, the participation of the applicants in the potential main hearing would not have further contributed to the trial court's assessment of the case.${ }^{91}$ As Ruggieri noted, the main question - whether the decision to apply a penal order procedure was justified - remained unanswered. ${ }^{92}$ The Court did not raise doubts on German procedural law, nor did it explain why the victim's involvement does not follow from the procedural requirements of Art. $2 \S 1$ of the Convention as conversely acknowledged in relation to

83 See Ruggieri, S., op. cit. note 76, p. 111.

84 Corte Costituzionale, ordinanza n. 124 of 16 April 1999. See Gaito, A., op. cit. note 40, p. 3025. In addition, the constitution of a civil party in a hearing set for the application of a penalty upon the request of the parties following the opposition of a penal order is not admissible. Cassazione Penale, Sezioni Unite, sentenza n. 47803, of 27 November 2008.

85 For details, see Pradel. J., Procédure Pénal, 17e Édition, Éditions Cujas Paris, 2013, p. 813.

86 Articles 495-2-1, 495-3-1 and 495-5-1 CCP.

87 Section 396(1) StPO.

88 ECtHR, Gray v. Germany, app. no. 49278/09, judgment 22 May 2014. See Ruggieri, S., op. cit. note 76, p. $303,473$.

89 The court found that there was no violation of Article 2 ECHR § 95 - 96.

90 Gray v. Germany, §61.

91 Ibid., §91.

92 Ruggieri, S., op. cit. note 76, p. 304. 
situations in which the responsibility of the state's agents in connection with a victim's death is at stake. ${ }^{93}$

\subsection{THE SIGNIFICANCE OF THE VICTIM'S CONSENT FOR ISSUING A PENAL ORDER}

Under the Croatian CPA, the victim's approval is irrelevant for the penal order procedure as it is not needed either for the decision on requesting the issuance of a penal order or for the penalties and other measures imposed by the penal order. In contrast, the victim's consent is required for the application of the conditional deferral or withdrawal of criminal prosecution, another consensual mechanism applicable for minor criminal offences punishable by up to five years (Art. 206.d CPA). However, except in the aforementioned case, the victim's consent is not required for a judgment on the basis of an agreement between the parties, except in the case of serious criminal offences: criminal offences against life and limb or against sexual freedom punishable by more than five years of imprisonment (Art. 360(6) CPA). ${ }^{94}$

German criminal procedure law, like Croatia's, does not require the consent of the victim to issue a penal order. Italian law, however, has shown a different approach. In 1999, an additional negative requirement for issuing a penal order was prescribed in the cases of criminal proceedings for offences prosecutable upon the victim's complaint, that is, the complainant has not expressed an intention to oppose the issuing of a penal order. ${ }^{95}$ However, in 2015 the Constitutional Court declared as unconstitutional paragraph 1 Art 459 CCP in the part in which it provides for the complainant's right to oppose the issuing of a penal order with the argumentation that it causes an infringement of the principle of the reasonable duration of a trial, without the same being justified by the protection requirements of the complainant or victim. ${ }^{96}$ Therefore, in Italian law the (tacit) consent of the victim is no longer a requirement for the issuance of a penal order.

In France, however, unlike Croatian law, the will of the victim to some extent affects the possibility of issuing a penal order. Thus, in cases of petty offences (contraventions), if the vic-

93 Gray v. Germany, § 87. Ruggieri, S. op. cit. note 76, p. 476.

94 On the victim's role in consensual forms in Croatian criminal procedure, see Ivičević Karas, E., op. cit. note 8, p. 425-426.

95 Ruggieri, S., op. cit. note 76, p. 111.

96 See Ruggieri, S., Procedimento per decreto penale e opposizione preventiva del querelante. Linee-guida per un modello partecipativo di giustizia penale monitoria,

Http://www.processopenaleegiustizia.it/procedimento-decreto-penale-opposizione-querelante-Linee-guida. Accessed 27 January 2021., Corte Costituzionale, sentenza n. 23, 2015 of 28 January 2015, paragraph 2.5, https://www.giurcost.org/ decisioni/2015/0023s-15.html. Accessed 28 January 2021. 
tim decides to summon the defendant directly before the court ${ }^{97}$ before the penal order has been issued, the procedure of the penal order can no longer be continued. ${ }^{98}$

\section{CONCLUSION}

The penal order procedure, the first consensual criminal procedure introduced in Croatia in its almost 25 years of existence, has undergone important changes both in legislation and in practice. Due to the adjustments, the penal order procedure is a widely used mechanism in the Croatian criminal justice system that promotes the values of efficiency economy and the fast resolution of criminal proceedings. However, it can be seen that the rule of law concern of lawfulness is present as the procedural reality does not correspond to the legal terms and the procedural provisions on the penal order prescribed in the Criminal Procedure Act.

As concerns the range of offences for which a penal order may be issued, it is applicable to offences punishable by imprisonment of up to five years, including a wide range of offences, among which are serious ones such as fraud, threat, forging documents, aggravated theft, illicit trade and serous criminal offences against general safety. In comparison, in Italy the penal order procedure is limited to offences punishable by up to six months of imprisonment replaceable by a fine, in Germany to offences punishable by up to one year of imprisonment, in Austria to offences punishable by up to three years, in France, as in Croatia, to offence offences punishable by up to five years, while Switzerland is the only country that allows a penal order for all offences. However, the range of offences does not tell us about the severity of the sentences imposed by a penal order in concrete criminal proceedings as there is a limitation of its application with regard to permissible sanctions.

As concerns the type or amount of sentence that can be imposed by a penal order, Croatia has also thoroughly transformed penal order sentences, starting in 1997 from mild sentences such as a fine, admonition, confiscation, seizure and prohibition to operate a motor vehicle, and ending in 2008 with a suspended prison sentence of up to one year. A suspended sentence may result in imprisonment of up to one year in cases where a convicted person does not fulfil the conditions ordered in the suspended sentence or commits a new crime. In practice in Croatia, the suspended sentence of imprisonment is by far the most common sentence in penal order judgments, amounting to more than $90 \%$ of cases. Therefore, it can be concluded that in Croatia the speedy procedure without a trial in the form of a penal order introduced in 1997 has been converted in law and in practice from a procedure excluding any conditional or unconditional deprivation of liberty to a procedure regularly imposing imprisonment in the form of a suspended sentence.

97 The victim can initiate proceedings either before the instruction judge (plainte avec constitution de partie civile) or before the courts (citation directe), McKee, J.-Y., Criminal Justice Systems in Europe and North America. Helsinki, Finland: HEUNI, European Institute for Crime Prevention and Control, affiliated with the United Nations, 2001, p. 39. http://old.heuni.fi/material/ attachments/heuni/profiles/6Ku1K168F/France.pdf. Accessed 20 February 2021. 
Such a grave sentence in a summary procedure such as the penal order procedure is a rarity in the European context. In France and Italy, a prison sentence is excluded in any form. In Germany and Austria, a penal order may impose a suspended prison sentence of up to one year. Swiss law stands as an exception where a public prosecutor can impose through a penal order a custodial sentence of up to six months. Therefore, as a result of the constant expansion in the field of the application of the penal order since its introduction in 1997, Croatia is among the states with the widest range of criminal offences and the highest sentences under the penal order.

However, to be able to assess the fairness of proceedings that include severe sentences, account has to be taken of the procedural nature of proceedings and the procedural safeguards such as judicial control, defence rights and victims' rights.

The evidential standard for issuing a penal order in Croatia, the "credible content of the crime report" differs from the solutions in other states. The original 1997 concept of the procedure that precedes the conclusion of the existence of a credible crime report that excluded the taking of any additional evidentiary actions from the prosecutor or judge was abandoned. In practice, it was accepted that the prosecutor is permitted to collect all evidence after the crime report is filed and even to conduct a simplified investigation. The interrogation of the defendant becomes in practice an obligatory requirement for issuing a penal order. Therefore, the judgment on a penal order could be issued even in the case where the content of the crime report at the time of filing was not credible, i.e. it was not sufficient to conclude that the defendant had committed a criminal offence, although evidence gathered later in a simplified investigation led to that conclusion. In view of all the above, we propose that a credible crime report as a requirement for the state attorney to request a penal order should de lege ferenda be omitted as an evidential standard.

Regarding judicial review before the issuing of a penal order, comparative analysis of systems reveals that although there are differences in the scope of judicial control, its focus is on the evidence, reviewing whether sufficient probability has been established for moving into the trial stage or whether there is a lack of proof or other reasons for acquittal. Croatian law disregards the admissibility of evidence in the judicial review of the indictment before or after issuing a penal order, although it is issued on the basis of evidence collected before or during a simplified investigation. Therefore, compared to the judicial review of the indictment in the proceedings where the state attorney did not request a penal order, there is a substantial lowering of the fair trial guarantees, the extent of the judicial review of the investigation, and the legality of the evidentiary acts.

The control of formal requirements is also limited unsatisfactorily, since a single judge does not control whether the indictment was filed within the time limits or whether the indictment contains all the necessary parts. This could lead to a judgment being rendered even though there were some legal impediments to conduct criminal proceedings. We propose that the judicial control of all formal requirements be introduced in the penal order proceedings. This could be done either by broadening the powers of the single judge to review the indictment before issuing a penal order or by empowering the indictment panel to review such an indictment. In both cases, this would protect the rights of defendants and prevent the issuance of penal orders in situations of procedural impediments. 
As concerns the protection of defence rights, the penal order procedure in Croatia in its original form did not foresee the participation of the defendant and did not foresee any defence rights. However, the introduction of evidentiary acts in practice led to the introduction of defence rights. Therefore, we propose that the interrogation of the defendant is a key element in safeguarding defence rights that should be explicitly prescribed by law and fall under judicial control. In the case of conducting a simplified investigation, the defendant has an additional set of defence rights in the penal order procedure. Comparative research shows that there are systems, such as the Austrian one, which provide the defendant with strong participatory rights and procedural guarantees before the issuing of a penal order.

In regard to the position of the victim, comparative analysis has revealed that, with some exceptions (Austria, France), the role of the victim and the victim's participatory rights in a penal order procedure are generally narrowed and reduced to the possibility of filing a pecuniary claim. As for the CPA, some inconsistencies were detected in connection with the rights that the law grants victims and injured persons. A way should be found to explicitly allow the victim to exercise rights in penal order proceedings, particularly those such as submitting pecuniary claims, drawing attention to facts, and proposing evidence.

However, the question remains as to why, for the same offence (even with the same sanction proposal by the state attorney), judicial review, exclusion of illegal evidence, defence rights, victims' rights and other procedural safeguards differ depending on the discretionary decision of the public prosecutor as to whether to request the issuance of a penal order. Therefore, the most effective solution and the one best oriented towards defence and victims' rights which also reflects and accepts the solutions developed in practice is to abandon the penal order procedure altogether and to introduce a penal order as a judicial decision that can be requested by the state attorney and rendered by the judge during the inquiries or preliminary investigation. This would afford the same level of protection irrespective of whether or not the state attorney requested a penal order.

\section{REFERENCES}

1. Bonačić, M., Kritički osvrt na hrvatsko zakonodavno uređenje instituta kaznenog naloga, Hrvatski ljetopis za kazneno pravo i praksu, Vol. 22, No. 1, 2015, pp. 185-216.

2. Carić, M., Istraživanje - zakonodavni okvir i praktična primjena, Hrvatski ljetopis za kaznene znanosti i praksu, Vol. 25, No. 2, 2018. p. 513-546.

3. Carić, M., Penal Order in the Light of Limitations and Excluding the Application of Certain Fundamental Principles of Criminal Procedure, Iustinianus Primus Law Review, Vol. 11, No. 2, 2020, pp. 1-19.

4. Damaška, M., Napomene o sporazumima u kaznenom postupku, Hrvatski ljetopis za kazneno pravo i praksu, Vol. 11, No. 1, 2004, pp 3-20.

5. Enescu, R., Penal Orders and the Role of Prosecutors in Switzerland, Journal of Legal Studies Volume 26 Issue 40/2020, pp. 125-141.

6. Gaito, A. (ed), Codice di procedura penale, Commentato, Utet Giuridica, 2012. 
7. Gillièron, G., Public Prosecutors in the United States and Europe: A Comparative Analysis with Special Focus on Switzerland, France, and Germany, Springer, 2014.

8. Ivičević Karas, E., Consensual Justice in Croatian Criminal Procedural Law: The Need for a Systematic Approach, EU and Comparative Law Issues and Challenges Series (ECLIC), Vol. 4, 2019, pp. 405-432.

9. Ivičević, E., Novosel, D., Vrste i mjere kazne primjenjivane u instrumentu kaznenog naloga i njihov odnos prema izrečenim kaznama, Hrvatski ljetopis za kazneno pravo i praksu, Vol. 11, No. 2, 2004, pp. 675-699.

10. Klier, D., Kondor-Langer, M., Gluščić, S., Policijska i državnoodvjetnička praksa u ispitivanju osumnjičenika, Hrvatski ljetopis za kaznene znanosti i praksu, Vol. 25, No. 2, 2018, pp. 447-475.

11. Krapac, D. et al., Kazneno procesno pravo. Prva knjiga: Institucije, Narodne novine, Zagreb, 2020.

12. Krapac, D., Zakon o kaznenom postupku i drugi izvori hrvatskog kaznenog postupovnog prava, Narodne novine, Zagreb, 2008.

13. Mazalin, S., Skraćeni postupak i ostali posebni postupci u Prijedlogu Zakona o kaznenom postupku, Hrvatski ljetopis za kazneno pravo i praksu, Vol. 15, No. 2, 2008, pp. 753-773.

14. Novosel, D., Primjena kaznenog naloga u radu državnih odvjetništava, Hrvatski ljetopis za kaznene znanosti i praksu, Vol. 9, No. 1, 2002, pp. 37-61.

15. Novosel, D. (ed.), Priručnik za rad državnih odvjetnika, Državno odvjetništvo Republike Hrvatske, 2011.

16. Pavičić, A., Bonačić, M., Skraćeni postupak prema novom Zakonu o kaznenom postupku, HLJKPP, vol. 18, 2/2011, pp. 489-520.

17. Petković, N., Pajčić, M., Kazneni progon, istraga i optuživanje - nova iskustva, Hrvatski ljetopis za kaznene znanosti i praksu, vol. 18, no. 2, 2011, pp. 417-447.

18. Pradel. J., Procédure Pénal, $17^{\circledR}$ Édition, Éditions Cujas Paris, 2013.

19. Ruggeri, S., Audi Alteram Partem in Criminal Proceedings, Towards a Participatory Understanding of Criminal Justice in Europe and Latin America, Springer International Publishing AG, 2017.

20. Thaman, S.C., The Penal Order: Prosecutorial Sentencing as a Model for Criminal Justice Reform? In: Luna, E., Wade, M. (eds): The Prosecutor in Transnational Perspective Oxford University Press, 2012.

21. Vriend, K., Avoiding a Full Criminal Trial, Fair Trial Rights, Diversions and Shortcuts in Dutch and International Criminal Proceedings, Springer, 2016.

\section{LIST OF REGULATIONS AN ACTS AND COURT DECISIONS}

1. Cassazione penale, Sez. III, sentenza n. 16894 of 23 April 2015

2. Cassazione Penenale, Sezioni Unite, sentenza n. 47803, of 27 November 2008

3. Code de procédure pénale, https://www.legifrance.gouv.fr/codes/id/LEGITEXT000006071154/

4. Codice di procedura penale, https://www.altalex.com/documents/codici-altalex/2014/10/30/codice-di-procedura-penale. Accessed 20 February 2021

5. Corte Costituzionale, ordinanza n. 124 of16 April 1999

6. Corte Costituzionale, sentenza n. 23, 2015 of 28 January 2015 
7. Directive 2012/29/EU of the European Parliament and of the Council of 25 October 2012 establishing minimum standards on the rights, support and protection of victims of crime, and replacing Council Framework Decision 2001/220/JHA, OL 315/57

8. Directive 2013/48/EU of the European Parliament and of the Council of 22 October 2013 on the right of access to a lawyer in criminal proceedings and in European arrest warrant proceedings, and on the right to have a third party informed upon deprivation of liberty and to communicate with third persons and with consular authorities while deprived of liberty, OJ L 294, 6 November 2013

9. ECHR, Gray v. Germany, app. no. 49278/09, judgment 22 May 2014

10. Kazneni zakon, Official Gazette no.125/11, 144/12, 56/15, 61/15, 101/17, 118/18, 126/19

11. Rješenje USRH, U-I-448/2009 $i d r$., of 19 July 2012

12. Poslovnik državnog odvjetništva, Official Gazette, no. 128/2019

13. Strafprozeßordnung, https://www.gesetze-im-internet.de/stpo/StPO.pdf. Accessed 20 February 2021

14. Strafprozeßordnung, https://www.jusline.at/gesetz/stpo. Accessed 20 February 2021

15. Ustav Republike Hrvatske, Official Gazette, no. 56/1990, 135/1997, 113/2000, 28/2001, 76/2010 and $5 / 2014$

16. VSRH, Kzz 1/14-3 of 28 January 2014

17. Zakon o kaznenom postupku, Official Gazette of the Republic of Croatia (Narodne novine), no. 110/1997

18. Zakon o kaznenom postupku, Official Gazette, no. 152/2008, 76/2009, 80/2011, 121/2011, 91/2012, 143/2012, 56/2013, 145/2013, 152/2014, 70/2017, 126/2019, 126/2019

\section{WEBSITE REFERENCES}

1. Croatian Bureau of Statistics, First Release: Legal entities perpetrators of criminal offences, by type of decision for 2015, 2016, 2017, 2018 and 2019. https://www.dzs.hr. Accessed 27 January 2021

2. McKee, J.-Y. Criminal Justice Systems in Europe and North America. Helsinki, Finland: HEUNI, European Institute for Crime Prevention and Control, affiliated with the United Nations, 2001, http:// old.heuni.fi/material/attachments/heuni/profiles/6Ku1K168F/France.pdf. Accessed 20 February 2021

3. Ruggieri, S., Procedimento per decreto penale e opposizione preventiva del querelante. Linee-guida per un modello partecipativo di giustizia penale monitoria, http://www.processopenaleegiustizia.it/procedimento-decreto-penale-opposizione-querelante-Linee-guida. Accessed 27 January 2021

4. Statistical Reports of Croatian Bureau of Statistics: Adult Perpetrators of Criminal Offences, Reports, Accusations and Convictions for 2015, 2016, 2017, 2018 and 2019. https://www.dzs.hr. Accessed 27 January 2021 
Zlata Đurđević*

Marin Bonačic***

Marija Pleić***

\section{UPITNOST VLADAVINE PRAVA U HRVATSKOM POSTUPKU ZA IZDAVANJE KAZNENOG NALOGA U VEZI S ODUZIMANJEM SLOBODE, SUDSKOM KONTROLOM, ZAKONITOŠĆU DOKAZA I POSTUPOVNIM PRAVIMA}

\section{Sažetak}

Rad se bavi institutom kaznenog naloga kao konsenzualnog postupka usmjerenog k rasterećenju kaznenopravnog sustava u slučajevima lakših kaznenih djela izbjegavanjem vođenja rasprave. Cilj mu je analizirati hrvatski normativni okvir i sudsku praksu kako bi se u poredbenom pravnom kontekstu utvrdile prepoznatljive osobine postupka za izdavanje kaznenog naloga, razotkrila procesna stvarnost i utvrdili nedostatci. Rad se usredotočuje na materijalne i postupovne zahtjeve za izdavanje kaznenog naloga, sudsku kontrolu optužnice kojom se traži izdavanje kaznenog naloga, prava obrane u postupku prije izdavanja kaznenog naloga i položaj žrtve. Ti su ključni elementi istraženi kroz normativnu, teorijsku i komparativnu analizu njemačkog, austrijskog, talijanskog i francuskog prava, a zaključci preispitani istraživanjem sudske prakse Općinskog kaznenog suda u Zagrebu i Općinskog suda u Splitu. Rezultati istraživanja otkrivaju kako proširenje primjene kaznenog naloga na teža djela za koja je predviđena kazna zatvora u trajanju od pet godina i na strože kazne kao što je oduzimanje slobode uz odstupanje od pojedinih temeljnih kaznenoprocesnih načela - svojstveno postupku za izdavanje kaznenog naloga - otvara pitanje pružanja odgovarajućih procesnih jamstava za okrivljenika i žrtvu.

Ključne riječi: $\quad$ kazneni nalog, postupovna jamstva, sudska kontrola, konsenzualnost, kazneni postupak, prava obrane

\section{(c) (1) (8)}

This work is licensed under a Creative Commons

Attribution-NonCommercial 4.0 International License.

\footnotetext{
* Dr. sc. Zlata Đurđević, redovita profesorica Pravnog fakulteta Sveučilišta u Zagrebu, Trg Republike Hrvatske 14, 10000 Zagreb. E-adresa: zlata.durdevic@pravo.hr. ORCID: https://orcid.org/0000-0003-0155-442X.

** Marin Bonačić, docent Pravnog fakulteta Sveučilišta u Zagrebu, Trg Republike Hrvatske 14, 10000 Zagreb. E-adresa: marin. bonacic@pravo.hr. ORCID: http://orcid.org/0000-0001-9951-0921.

*** Marija Pleić, docentica Pravnog fakulteta Sveučilišta u Splitu, Domovinskog rata 8, 21000 Split. E-adresa: marija.pleic@pravst. hr. ORCID: https://orcid.org/0000-0001-8868-0079.
} 
